\title{
РЕАЛІЗАЦІЯ ОКРЕМИХ ПРАВ ІНШОЇ ОСОБИ, ПРАВА ЧИ ЗАКОННІ ІНТЕРЕСИ ЯКОЇ ОБМЕЖУЮТЬСЯ ПІД ЧАС ДОСУДОВОГО РОЗСЛІДУВАННЯ
}

Жовтан П. В., Кравцова Л. Ю.

\begin{abstract}
У статті розглянуто питання правової регламентації прав та обов'язків іншої особи, права чи законні інтереси якої обмежуються під час досудового розслідування як учасника кримінального процесу. Визначено, що дослідження особливостей механізму забезпечення конституційних прав особи під час проведення досудового розслідування неможливе без дослідження сутності та змісту діяльності учасників кримінального провадження, які його здійснюють чи залучаються до його проведення. 3 огляду на зазначене зауважено, що віднесення іншої особи до кола учасників кримінального провадження передусім повинно передбачати наявність у неї певних процесуальних обов'язків і прав. Надано теоретичне обгрунтування щодо необхідності внесення змін доповнень до положень чинного КПК України з питань чіткої регламентації прав та обов'язків іншої особи, права чи законні інтереси якої обмежуються під час досудового розслідування як учасника кримінального nрочесу.
\end{abstract}

Виокремлено проблемні аспекти обмеження конституційних прав іншої особи, права чи законні інтереси якої обмежуються під час досудового розслідування в частині проведення обшуку. Зокрема, відзначається, що Законом не передбачено можливості залучення адвоката для надання безоплатної правової допомоги особам, права яких обмежуються під час проведення обшуку, за ініціативою органу досудового розслідування, прокурора. Указані обставини в контексті процесуального провадження можуть сприяти як порушенню права на захист особам, у яких проводиться обшук, так і нівелювати цілі та результати цієї слідчої дії, оскільки недопущення адвоката до цієї слідчої дії згідно зі статтею 87 КПК України $\epsilon$ підставою для визнання доказів недопустимими. Зазначено, що для забезпечення належної правової процедури закриття кримінального провадження за 4. $9 \mathrm{~cm} .284$ КПК України необхідно регламентувати права іншої особи, права чи законні інтереси якої обмежуються під час досудового розслідування, ї представника.

Ключові слова: інша особа, права чи законні інтереси якої обмежуються під час досудового розсліду-

( С Жовтан П. В., Кравцова Л. Ю., 2020 вання, права, обов'язки та законні інтереси, оскарження, досудове розслідування.

Zhovtan P. V., Kravtsova L. Yu. Exercise of individual rights of another person, the rights or legal interests of which are restricted during the pre-trial investigation

The article considers the issue of legal regulation of the rights and obligations of another person, whose rights or legitimate interests are limited during the pretrial investigation as a participant in criminal proceedings. It is determined that the study of the peculiarities of the mechanism of ensuring the constitutional rights of a person during the pre-trial investigation is impossible without studying the nature and content of the activities of participants in criminal proceedings who carry it out or are involved in its conduct. In view of the above, it has been noted that the assignment of another person to the circle of participants in criminal proceedings should, first of all, presuppose that he or she has certain procedural obligations and rights. Theoretical substantiation is provided on the need to amend the provisions of the current CPC of Ukraine on clear regulation of the rights and obligations of another person, whose rights or legitimate interests are limited during the pre-trial investigation as a participant in criminal proceedings. The problematic aspects of restricting the constitutional rights of another person or whose legitimate interests are limited during the pre-trial investigation in terms of conducting a search are highlighted. In particular, it is noted that the Law does not provide for the possibility of hiring a lawyer to provide free legal aid to persons whose rights are restricted during a search, at the initiative of the pre-trial investigation body, the prosecutor. These circumstances in the context of procedural proceedings may contribute both to the violation of the right to defense of persons under investigation and to neutralize the purposes and results of this investigative action, as the exclusion of a lawyer from this investigative action under Article 87 of the CPC of Ukraine is grounds for inadmissible evidence.

Key words: another person whose rights or legitimate interests are limited during the pre-trial investigation, rights, responsibilities and legitimate interests, appeals, pre-trial investigation. 
Постановка проблеми та іï актуальність. Визначення особливостей механізму забезпечення конституційних прав особи під час проведення досудового розслідування неможливе без дослідження сутності та змісту діяльності учасників кримінального провадження, які його здійснюють чи залучаються до його проведення. Згідно з п. 16-1 ч. 1 ст. 3 КПК України, під терміном «інша особа, права чи законні інтереси якої обмежуються під час досудового розслідування» варто розуміти особу, стосовно якої (у тому числі щодо ії майна) здійснюються процесуальні дії, визначені КПК України. Відповідно до п. 25 ст. 3 КПК України, «інша особа, права чи законні інтереси якої обмежуються під час досудового розслідування» віднесено до учасників кримінального провадження [1]. Разом із тим Глава 3 КПК України, що визначає, зокрема, сторін та інших учасників кримінального провадження, взагалі не містить відомостей стосовно іншої особи, права чи законні інтереси якої обмежуються під час досудового розслідування, у зв'язку з чим законодавцем залишено поза увагою визначення прав та обов'язків такого учасника кримінального провадження. 3 огляду на зазначене слід зауважити, що віднесення іншої особи до кола учасників кримінального провадження передусім повинно передбачати наявність у неї певних процесуальних обов'язків і прав. Проте невизначеність кримінального процесуального закону щодо правового статусу іншої особи, права чи законні інтереси якої обмежуються під час досудового розслідування, на тлі лише визначення іїі поняття, створює умови для віднесення до числа таких учасників доволі невизначеного кола осіб із невизначеними правами та обов'язками. У зв'язку із цим виникає необхідність у чіткому визначенні процесуального статусу іншої особи, права чи законні інтереси якої обмежуються під час досудового розслідування, що потребує критичного осмислення як уже усталених, так і нових теоретичних положень стосовно визначення процесуального статусу осіб, які беруть участь у кримінальному провадженні.

Аналіз останніх досліджень і публікацій. Проблемні питання процесуального статусу та участі інших учасників кримінального процесу у кримінальному провадженні досліджувалися Ю.П. Аленіним, А. Дубинським, І.В. Гловюк, О.В. Капліною, Л.М. Лобойком, Т.О. Лоскутовим, М.А. Погорецьким, О.Ю. Татаровим, М. Шумило, С. Стахівським, Л. Удаловою, В. Тертишником та іншими науковцями. Однак поява в положеннях чинного КПК України з листопада 2017 р. учас- ника кримінального процесу з таким широким визначенням, як «інша особа, права чи законні інтереси якої обмежуються під час досудового розслідування», вимагає відповідного дослідження.

Метою статті $\epsilon$ розгляд та аналіз з урахуванням законодавчих змін питання щодо визначення процесуального статусу іншої особи, права чи законні інтереси якої обмежуються під час досудового розслідування, процесуального статусу таких осіб; визначення проблем реалізації прав іншої особи, права чи законні інтереси якої обмежуються під час досудового розслідування, надання пропозицій щодо вдосконалення чинного кримінального процесуального законодавства із цього питання.

Виклад основного матеріалу. Передусім зауважимо, що згідно із завданнями кримінального провадження, визначеними ст. 2 КПК України, права, свободи й законні інтереси кожної особи, яка залучається до кримінального провадження як його учасник, повинні бути захищені. Перелік осіб, які підпадають під п. 16-1 ст. 3 КПК України, $\epsilon$, по суті, відкритим, i, як слушно зауважується, дотепер остаточно не вирішено, кого саме слід уважати такою «іншою особою». До цієї категорії можна віднести значну кількість суб'єктів кримінальних процесуальних відносин. Наприклад, О. Татаров стверджує, що до цієї категорії можна віднести значну кількість суб'єктів кримінальних процесуальних відносин: особу, стосовно якої здійснюється досудове розслідування (особу, якій не вручено повідомлення про підозру, але орган досудового розслідування збирає докази щодо ії причетності до вчинення кримінального правопорушення); особу, стосовно якої проводяться негласні слідчі (розшукові) дії; власника житла чи іншого володіння, де проводиться обшук; особу, котра перебуває в житлі чи іншому володінні під час обшуку, але не $\epsilon$ його власником; особу, щодо якої проводяться негласні слідчі (розшукові) дії; володільця тимчасово вилученого майна; володільця тимчасово вилучених речей та документів; третю особу, щодо майна якої вирішується питання про арешт [2]. Л.Ю. Слухай та Л.А. Чиж уважають, що до таких осіб можуть відноситися: статисти під час пред'явлення особи для впізнання; особи, щодо яких здійснюється досудове розслідування, проте про підозру їм ще не повідомлено; особи, у яких проводиться обшук; інші особи, які беруть участь у кримінальному провадженні [3]. І.В. Гловюк відзначає, що невирішеним, виходячи з положень КПК України, $\epsilon$ й питання 
стосовно можливості поєднання статусів іншої особи, права чи законні інтереси якої обмежуються під час досудового розслідування, зі статусом іншого учасника кримінального провадження [4, с. 159].

Відповідно до окремих положень КПК, інша особа має право на звернення до прокурора, слідчого судді або суду з клопотанням, в якому викладаються обставини, що зумовлюють необхідність здійснення кримінального провадження (або окремих процесуальних дій) у більш короткі строки, ніж передбачено Кодексом.

На досудовому провадженні такими особами може бути оскаржена бездіяльність слідчого, прокурора, яка полягає у: невнесенні відомостей про кримінальне правопорушення до Єдиного реєстру досудових розслідувань після отримання заяви чи повідомлення про кримінальне правопорушення; неповерненні тимчасово вилученого майна згідно з вимогами ст. 169 КПК; нездійсненні інших процесуальних дій, які він зобов'язаний учинити.

За положеннями ч. 9 ст. 284 КПК України інша особа, права чи законні інтереси якої обмежуються під час досудового розслідування, може звернутися з клопотанням до слідчого судді про закриття кримінального провадження, «якщо закінчилися строки досудового розслідування з моменту внесення відомостей про кримінальне правопорушення до Єдиного реєстру досудових розслідувань до дня повідомлення особі про підозру, встановлені частиною першою статті 219 цього Кодексу», однак у такому разі зі змісту ч. 9 ст. 284 КПК незрозуміло, що слід розуміти під поняттям «інша особа, права чи законні інтереси якої обмежуються під час досудового розслідування», яке відношення вона має до конкретного кримінального провадження i на якій підставі їй повинно надаватися право звертатися з клопотанням про закриття кримінального провадження, адже чинний КПК не оперує таким поняттям, як «інша особа, права чи законні інтереси якої обмежуються під час досудового розслідування». Натомість у ньому розкритий зміст термінів «сторони кримінального провадження» та «учасники кримінального провадження» (див. пункти 19, 25 ч. 1 ст. 3 КПК). Очевидно, що доповнення кримінального процесуального закону виключно поняттям «інша особа, права чи законні інтереси якої обмежуються під час досудового розслідування» $\epsilon$ недостатнім для повного гарантування права на захист від незаконного кримінального переслідування, оскільки такому учаснику кримінального провадження прямо не надано право на ознайом- лення з матеріалами кримінального провадження (ст. 221 КПК України), які прямо стосуються його прав та обов'язків. Необхідно конкретизувати перелік прав та обов'язків інших осіб, права чи законні інтереси яких обмежуються під час досудового розслідування. На нашу думку, у цій частині законодавче положення потребує додаткового уточнення. Убачаються два шляхи вирішення цього питання: 1) ухвалення роз'яснення Верховним Судом щодо прав та обов'язків інших осіб, права чи законні інтереси яких обмежуються під час досудового розслідування; 2) доповнити КПК України статтею із зазначенням вичерпного переліку прав та обов'язків інших осіб, права чи законні інтереси яких обмежуються під час досудового розслідування, а також передбачити відповідальність за їх порушення [5].

Пункт $16^{1}$ ст. 3 КПК України визначає, що інша особа, права чи законні інтереси якої обмежуються під час досудового розслідування, - особа, стосовно якої (у тому числі щодо їі майна) здійснюються процесуальні дії, визначені цим Кодексом. Відповідно, процесуальний статус така особа набуває з моменту «проведення процесуальної дії щодо особи (ії майна)». Уявляється, що можливість особи, права чи законні інтереси якої обмежуються під час досудового розслідування, реалізувати свої права та обов'язки залежить від того, як саме тлумачити зміст терміна «процесуальна дія».

Частина 1 ст. 5 КПК України унормовує, що процесуальна дія проводиться, а процесуальне рішення приймається згідно з положеннями цього Кодексу, чинними на момент початку виконання такої дії або прийняття такого рішення. Таким чином, чинний КПК України визначає, що будь-яка дія, яка проводиться під час кримінального провадження, $є$ процесуальною.

Окрім того, ст. 103 КПК України, що регулює форми фіксування кримінального провадження, установлює, що процесуальні дії під час кримінального провадження можуть фіксуватися у: протоколі; на носії інформації, на якому за допомогою технічних засобів зафіксовано процесуальні дії; у журналі судового засідання. Зважаючи на вказане, процесуальна дія в кримінальному провадженні має такі ознаки: проведення та відповідна форма фіксування.

Проте, як видається, для реалізації та використання цього механізму для відстоювання прав та законних інтересів іншої особи, права чи законні інтереси якої обмежуються під час досудового розслідування, не вистачає низки положень, які б уточнювали їі механізм. 
Зокрема, Законом не передбачено можливості залучення адвоката для надання безоплатної правової допомоги особам, права яких обмежуються під час проведення обшуку, за ініціативою органу досудового розслідування, прокурора. У такій ситуації особа, у якої проводиться обшук, не має статусу підозрюваного за винятком, коли вона $\epsilon$ затриманою або їй оголошено підозру на момент проведення цієї слідчої дії. Згідно зі ст. 236 КПК, для участі в проведенні обшуку можуть бути запрошені потерпілий, підозрюваний, захисник, представник та інші учасники кримінального провадження. Незалежно від стадії цієї слідчої дії слідчий, прокурор, інша службова особа, яка бере участь у проведенні обшуку, зобов'язані допустити на місце його проведення захисника чи адвоката, повноваження якого підтверджуються згідно з положеннями ст. 50 КПК.

Відповідно до ст. 49 КПК, безоплатний захисник може бути залучений лише для особи, що має статус підозрюваного чи обвинуваченого, за iї клопотанням. Згідно із Законом України «Про адвокатуру та адвокатську діяльність», захист $\epsilon$ видом адвокатської діяльності, що полягає у забезпеченні захисту прав, свобод і законних інтересів підозрюваного, обвинуваченого, підсудного, засудженого, виправданого, особи, стосовно якої передбачається застосування примусових заходів медичного чи виховного характеру або вирішується питання про їх застосування в кримінальному провадженні, особи, стосовно якої розглядається питання про видачу іноземній державі (екстрадицію), а також особи, яка притягається до адміністративної відповідальності під час розгляду справи про адміністративне правопорушення.

У такій ситуації особа мусить самостійно звертатися до органів, які забезпечують надання безоплатної правової допомоги, з необхідним переліком документів, і питання забезпечення iii права на захист буде вирішено в 10-денний термін, адже відповідно до Закону України «Про безоплатну правову допомогу», право на безоплатну вторинну правову допомогу мають окремі категорії осіб, перелік яких чітко закріплений законодавством. Звернення про надання одного з видів правових послуг, передбачених ч. 2 ст. 13 цього Закону, подаються особами, які досягли повноліття, до Центру з надання безоплатної вторинної правової допомоги або до територіального органу юстиції за місцем фактичного проживання таких осіб. У разі звернення особи про надання одного з видів безоплатної вторинної правової допомоги БВПД зобов'язаний упродовж десяти днів із дати надходження звернення прийняти рішення щодо надання безоплатної вторинної правової допомоги.

Указані обставини в контексті процесуального провадження можуть сприяти як порушенню права на захист особам, у яких проводяться обшук, так і нівелювати цілі та результати цієї слідчої дії, оскільки недопущення адвоката до цієї слідчої дії згідно зі ст. 87 КПК України $\epsilon$ підставою для визнання доказів недопустимими [6].

Іншим проблемним питанням $\epsilon$ нормативна регламентація права іншої особи, права чи законні інтереси якої обмежуються під час досудового розслідування, на закриття кримінального провадження. Законодавець доповнив ст. 284 КПК України положенням, за яким учасники кримінального провадження мають право заявляти клопотання слідчому, прокурору про закриття кримінального провадження за наявності передбачених цим пунктом підстав.

У разі ж відмови слідчого, прокурора в задоволенні клопотання про закриття кримінального провадження 3 підстав, визначених п. 91 ч. 1 ст. 284 КПК України, стороною захисту, іншою особою, права чи законні інтереси якої обмежуються під час досудового розслідування, iї представником, таке рішення може бути оскаржено до слідчого судді в порядку, визначеному параграфом 1 Глави 26 КПК України, з можливістю перегляду відповідного рішення в апеляційному порядку в порядку ч. 3 ст. 307, ч. 2 ст. 309 КПК України.

Окрім того, ч. 9 ст. 284 КПК України унормовано, що в разі закінчення строків досудового розслідування з моменту внесення відомостей про кримінальне правопорушення до Єдиного реєстру досудових розслідувань (ЄРДР) до дня повідомлення особі про підозру, встановлених ч. 1 ст. 219 КПК України, слідчий суддя може винести ухвалу про закриття кримінального провадження за клопотанням іншої особи, права чи законні інтереси якої обмежуються під час досудового розслідування, або іï представника. Своєю чергою, ухвала слідчого судді про закриття кримінального провадження на підставі ч. 9 ст. 284 КПК України може бути оскаржена в апеляційному порядку на підставі п. 121 ч. 1 ст. 309 кПК України.

Для належної підготовки клопотання іншої особи, права чи законні інтереси якої обмежуються під час досудового розслідування, іiі представника про закриття кримінального провадження необхідно ознайомитися з матеріалами 
кримінального провадження. Однак ст. 221 КПК України, яка регламентує ознайомлення з матеріалами досудового розслідування до його завершення, прямо не передбачає право іншої особи, права чи законні інтереси якої обмежуються під час досудового розслідування, її представника про закриття кримінального провадження, іiї представника здійснювати таке ознайомлення, що може спричинити формальні відмови у задоволенні таких клопотань [4, с. 159]. Окрім того, порядок розгляду клопотання слідчим суддею КПК також не регламентовано, адже не встановлено підсудність клопотання; учасників розгляду і чи $\epsilon$ обов'язковою участь слідчого, прокурора; строки розгляду; обставини, які мають бути встановлені у ході розгляду (локальний предмет доказування); межі повноважень слідчого судді (зокрема, стосовно витребування матеріалів кримінального провадження, проведення допитів, дослідження документів та речових доказів тощо). Це викликає критику також у такому аспекті, що в КПК не передбачено права витребування провадження від слідчого, прокурора чи іншої процедури, яка дала б змогу переконатися у правильності кваліфікації, тобто чи належить цей склад злочину до тієї категорії, що може підлягати закриттю, чи не вбачається в матеріалах ознак іншого складу злочину та необхідності продовження його розслідування тощо [2].

Висновки. У сучасних умовах великого значення набуває дотримання конституційних прав особи під час проведення досудового розслідування, що $\epsilon$ невід'ємною умовою законності, обґрунтованості, доцільності й ефективності його проведення. Від дотримання цих умов стороною обвинувачення залежать допустимість зібраних доказів, забезпечення процесуальних прав сторони захисту, інших учасників досудового розслідування, які присутні під час його проведення, недопущення непропорційних обмежень конституційних прав відповідних осіб, а також належна реалізація засад кримінального провадження. Правова визначеність та вдале врегулювання правового статусу іншої особи, права чи законні інтереси якої обмежуються під час досудового розслідування, не лише сприятиме вдосконаленню теоретичних положень із питань правової конструкції його суб'єктів та їх функціонального призначення і правового статусу, а й дасть змогу уникати нечітких трактувань сто- совно участі таких учасників з одночасною можливістю як реалізації ними визначених законом прав, так і покладенням на них визначених законом обов'язків із моменту їх участі у кримінальному провадженні.

\section{Література}

1. Кримінальний процесуальний кодекс України від 13.04.2012 № 4651-VI. URL: https://zakon.rada. gov.ua/laws/show/4651-17/.

2. Татаров О. Дрібниці вирішують усе! Чергові зміни до КПК забезпечать хіба що колапс досудового розслідування. URL: https://zib.com.ua/ua/134754zmini_do__ kpk_zabezpechat_kolaps_dosudovogo_ rozsliduvannya.html.

3. Слухай Л.Ю., Чиж Л.А. Правовий статус іншої особи, права чи законні інтереси якої обмежуються під час досудового розслідування. URL: http:// dspace.onua.edu.ua/bitstream/handle/11300/10630 /17_\%D0\%A1\%D0\%BB\%D1\%83\%D1\%85\%D0\%B0\%D0\%B9\% 2C\%20\%D0\%A7\%D0\%B8\%D0\%B6_356-359.pdf?sequence= 1 \&isAllowed $=\mathrm{y}$.

4. Гловюк І.В. Право іншої особи, права чи законні інтереси якої обмежуються під час досудового розслідування, на закриття кримінального провадження: проблеми нормативної регламентації та реалізації. Вісник Південного регіонального центру Національної академії правових наук України. 2019. № 18. С. 158-165.

5. Іванець А. Довгоочікувані зміни до КПК. Взгдяд юриста : юр. блог к-нии Juгiшех 16.11.2017. URL: http: / / jurblog.cow.ua/2017/11/doygoochik:uyanizwini-do-kpk/.

6. Іллюк С. Деякі проблеми правового регулювання обшуку в Україні. URL: https://ecpl.com.ua/ news $/ 17795 /$.

Жовтан П. В., кандидат юридичних наук, суддя Комінтернівського районного суду Одеської області, доцент кафедри кримінального процесу одеського державного університету внутрішніх справ

Кравцова Л. Ю., аспірант кафедри кримінального процесу одеського державного університету внутрішніх справ 